suggested the powerful thematic and structural functions of this play within the Chester cycle.

ERIN E. KeLLY

\title{
Notes
}

1 'Chester Cycle 2010: Vassar College English 215 performs the Antichrist', <http:// blogs.vassar.edu/chestercycle/>.

\section{Miracles and Marvels: A View from the Third Station}

David Mills argues that the 'dramatic interest of the cycle focuses upon the different responses of characters to prophecy' and such 'dislocations of nature' ${ }^{1}$ as miraculous signs. Alexandra F. Johnson's edition of the 1572 text $^{2}$ strongly suggests that spectacular stage effects were called for in the representation of such miraculous signs of God's power and Christ's divinity, and these effects would probably have been instrumental to a given play's pedagogical and dramatic efficacy. The third day of pageants, set squarely in the time of the 'holy spirit', offered several interesting staged representations of miracles, 'false', and 'true', and provided an illuminating index of the disparate approaches the participating groups took.

'The Road to Emmaus' dramatizes Christ's visitation of the disciples following his resurrection and the subsequent episode of Thomas's doubt, and is punctuated throughout with the fantastic disappearances and reappearances of the newly-risen Christ. Redeemer College produced 'Emmaus', and their modest intention to honour the play's 'storytelling and teaching component' ${ }^{3}$ was served well enough. But the group's attempt 'to catch some of the wonder the disciples must have felt in that brief period when the risen Christ was appearing to them, and share it $^{\text {'4 }}$ was arguably less successful. These moments were cleverly blocked and made ample use of the simple set that consisted of a dressed table concealing a trap in the floor of the pageant wagon and a break in the curtain behind that was painted to look like the brickwork of the third station's mansion. Following one of Jesus's disappearances, the pilgrims swept the table away, demonstrating that he 


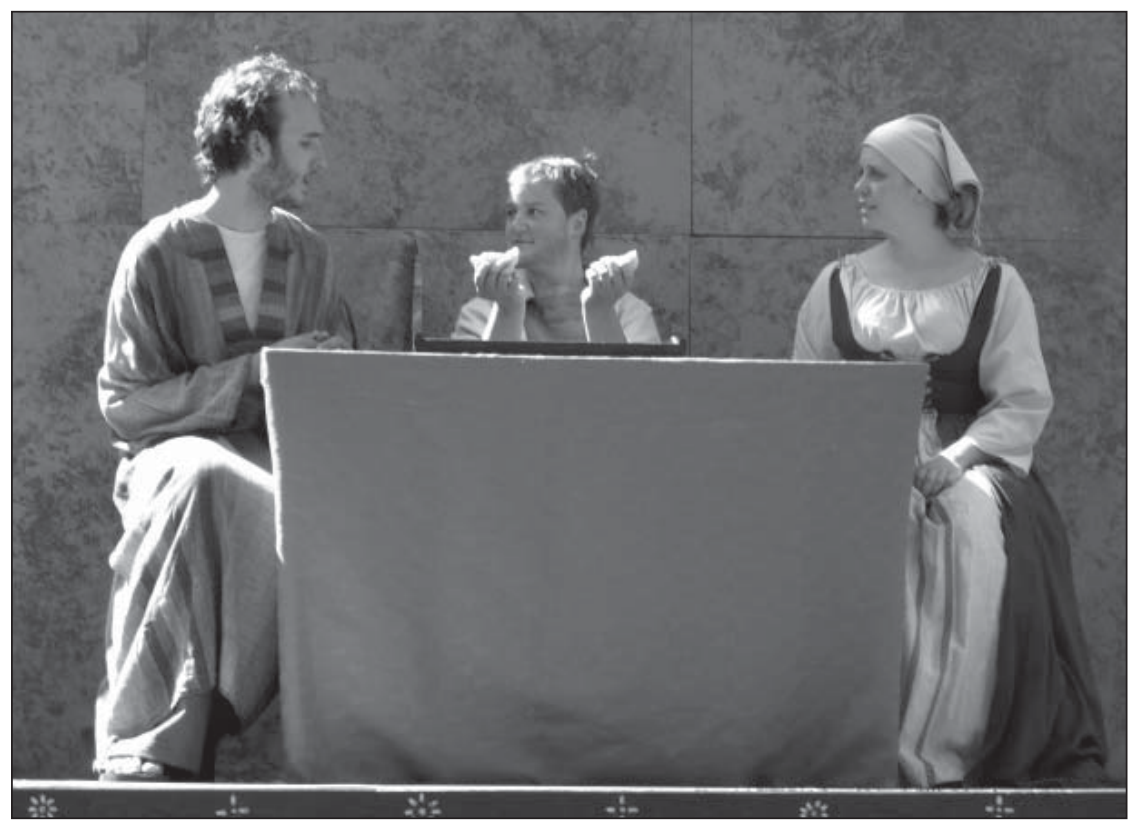

Fig. 11. Emmaus (Redeemer College). Courtesy of Heather S. Mitchell.

was not merely hiding behind it; however, the effect was more than slightly diminished by the visible break in the moving curtain behind them.

The characters' responses to such moments read as comic, as when Cleophas hammed his repetition of 'Alas' on Christ's first departure. This sense of lightness was reinforced when Christ reappeared, this time from behind the shaking out of a blanket, which brought to mind the farcical blanket-tossing of Mak in the Towneley Second Shepherd's Play. The moment cast Christ's reappearance as a parlour trick, a conventionalized 'illusion' that insisted on its theatricality and was coded as comic rather than 'wondrous'. As such, these effects resonated more with the objectively 'false' miracles of Antichrist, whose stage-managing grandstanding is marked as inauthentic not only by the legitimating authority of the archangel Michael and the cycle's overarching rationale, but by his self-consciously theatrical comic parodies of Christ's miracles.

The issue here is largely one of tone, and while characters' responses to miraculous 'dislocations of nature' in the cycle often read as comic, comedy tends to be associated with disbelief rather than wonder; there is little in the text of 'Emmaus' to suggest that Cleophas or the other disciples are as 
self-consciously amused or baffled by Christ's visitations as they were in this production. In 'Emmaus', all this comic business comes to an interesting head in the representation of Thomas's conversion to belief. Although the text calls for a blood effect, Christ's wounds were not visible. The moment contrasted sharply with the comic literalism of the disappearing-reappearing act that had characterized the play to that point. It relied for its quiet effect on Thomas's expression of awe, which was here unfortunately insufficient in its delivery to engender 'wonder'. This insufficiency also diminished the strength of Christ's subsequent address to the audience, in which he exhorts them to believe in his divinity. For a cycle in which staged incarnation is paramount, Christ's lack of visible wounds stood out as an interesting directorial choice that was perhaps meant to resonate with lines such as 'blessed must they all be / that believe and never see' (255-6). The staging might be seen to presume a community of faith whose transformational energies would provide the necessary suspension of disbelief, but ultimately it failed to convert this reviewer.

Under Peter Cockett's direction, McMaster University's 'The Last Judgment' achieved a level of polish and artistry that proved the dramatic potential of the text. The representation of divine signs in Vassar College's 'Antichrist' - reviewed here by Erin E. Kelly — provided an intriguing contrast to that of 'The Last Judgment', with its hypertheatrical and hilariously campy travesties of Christ's miracles of resurrection and the raising of the dead. The Vassar team played up the metatheatrical dimension of Antichrist's performance, inviting comparison with such stage-managing characters as Shakespeare's Richard III. Whereas the staging of 'Antichrist' reflected the chaos and dynamism of its antagonist as (s)he ranged about the yard, stage, and mansion, Cockett's production was a picture of control and divine order.

The most remarkable element of the set, apart from the angel-flanked cross at the top of the mansion, was a mirrored orb set into a pedestal onto which Jesus eventually descended. With one hand over his breast and the other held aloft, Christ sat in judgment with one foot resting on the reflecting globe that seemed to represent the world. The mirror simply and ingeniously implicated the audience in the cycle's cosmic design, bridging messianic and present time as it reflected the mingled images of the audience, the players, and the environs. This effect of temporal-spatial confusion was strengthened by the performance's consistent employment of audience address which was put to productive use long before John the Evangelist explicitly hails the audience in the epilogue. The redeemed and the 
damned occupied the space before the pageant wagon and the devils wove through the spectators, playfully threatening the small children in the audience. While the second devil's performance occasionally drifted into camp and the portrayal of the damned revealed a sense of fun in their colourful embodiment of their respective sins, the tone throughout was otherwise appropriately solemn and portentous.

The costuming of several of the damned as recognizable contemporary types foregrounded the anachronism characteristic of medieval theatre: a corrupt justice wore the robes and wig of a British magistrate and a greedy merchant appeared in the costume of a Bay Street executive, complete with cell phone headset. Despite the production's insistence on engaging the audience, what Mills calls the cycle's sense of 'the alterity of the past' came through in the actors' sensitive and often incantatory delivery of their lines as well as their deployment of precisely articulated rhetorical gestures that recalled the physical vocabulary of Cockett's productions for the Shakespeare and the Queen's Men project (SQM). ${ }^{6}$ The blocking, furthermore, deftly circulated the actors about the playing space, giving the presentation a pleasant visual flow while marking beats in the text by intermittently resolving the players into religiously resonant tableaux.

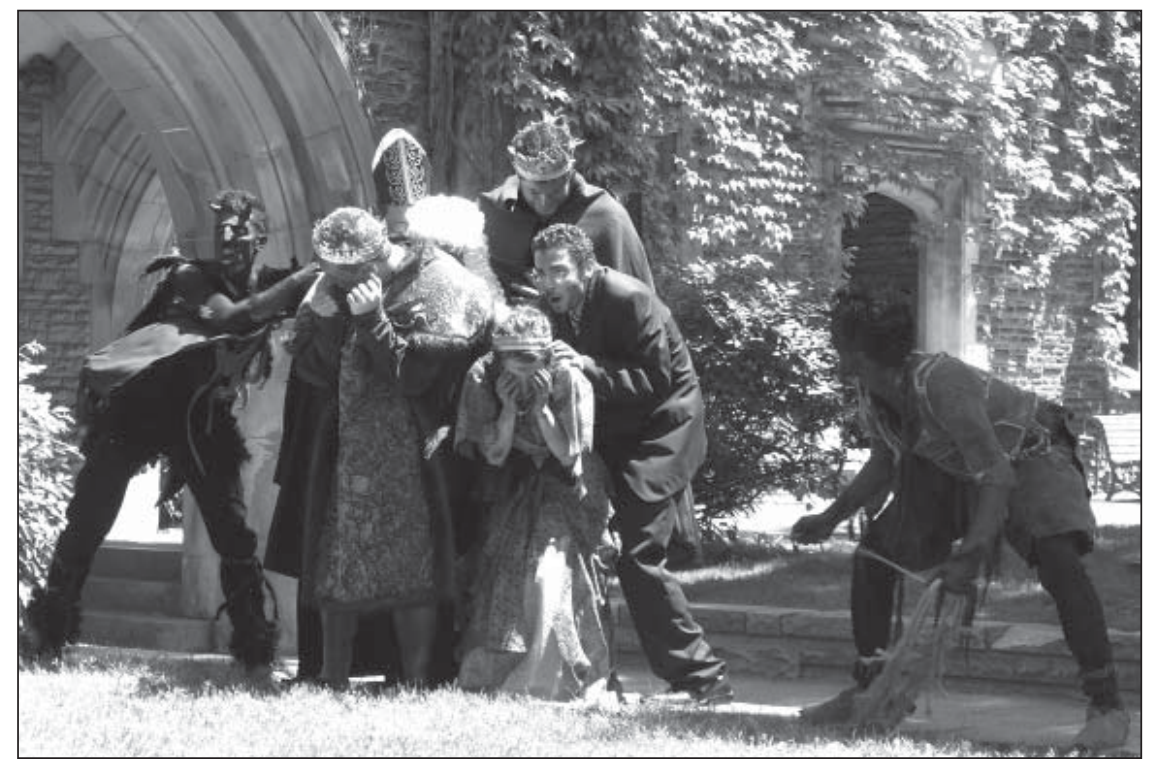

Fig. 12. 'The Last Judgment' (McMaster University). Courtesy of Heather S. Mitchell. 
Although the text states that, for his descent to earth, 'Jesus shall come down as if in a cloud, if it can be contrived' (23.365 SD), the effect was achieved more simply here, using the stairs. Spectacular emphasis fell ultimately on the miraculous streaming of blood from Christ's wound. A special effects artist contracted to produce a more spectacular effect withdrew at the last moment. While the means was relatively obvious (the actor appeared to have been concealing some kind of squib in his hand) the effect was powerful; the audience both onstage and off seemed appropriately awed and moved. In contrast to the self-conscious theatricality of Antichrist's stage-managing antics or the parlour tricks of 'Emmaus', the 'miracle' here derived its power from its simplicity, from the gravity and tonal control with which it was presented, and from its coherent integration in the overall stage image. The evangelists' admonitory epilogue served as a strangely flat postscript to the main action; presumably, the intended effect was to encourage that kind of critical reflection that Mills argues characterizes the plays' model of dramatic engagement. The deftness with which this shift was managed was characteristic of the production's masterful control of tone and image. In all, Cockett's 'Last Judgment' proved a thoughtful, moving, and deeply satisfying coda to Toronto's Chester Cycle.

Dimitry A. Senyshyn

\section{Notes}

1 David Mills, Recycling the Cycle: The City of Chester and its Whitsun Plays (Toronto, 1998), 168.

2 The Chester Plays, adapted as an acting text by Alexandra Johnston, assisted by Linda Phillips (2010), from the modernized version by David Mills.

3 From the notes on the 'Road to Emmaus' production posted on the Chester 2010 website, at <http://chester.uwaterloo.ca/index.php/chester/performance/play18>.

4 Ibid.

5 Mills, Recycling the Cycle, 164.

6 See Performing the Queen's Men <http://thequeensmen.ca>. 